\title{
Sat 3
}

\section{7年度ダニ類研究班集会}

内 容：1. 話 題「ヤマトマダニのこと」

本種は人寄生がよく知られる普通種で、最近は病原体との関連 が注目されるので、種々の話題 (下記抄録) を通して論議したい。

\section{2. 全体会議 1997年度の活動方針について}

\section{抄 録}

1.ヤマトマダニの分類と分布

高田伸弘（福井医科大学）

本種は北海道から屋久島まで生息が知られるが、周辺国でみられる個体群との 絡みで分類学的な曲折もあった。ここでは本種の宿主関係や地理・垂直分布の特 特徵をまとめておく。

2.ヤマトマダニの生活史

藤本和義（埼玉医科大学）

ここではヤマトマダニの季節的消長について述べる。また、温度や日長などの 季節要因が産卵や発育に及ぼす影響を調べ、ヤマトマダニの生活史がこれらの季 節要因によって調節されていることに言及する。

3.ヤマトマダニのヒト刺咬症例 初鹿了(川崎医科大学)

本邦におけるマダ二類のヒト刺咬症は、ヤマトマダニによるものが圧倒的に多 い（山口、1989）。演者は、1974年以降に本邦で報告された本種のヒト刺咬例に ついて文献的に検討したので、その概要を述べる。

4. ダ二媒介性ウイルス脳炎 高橋健一（北海道立衛生研究所）

ダ二媒介性脳炎としては、中央ヨーロッパダニ脳炎やロシア春夏脳炎が知られ るが、わが国ではその存在は不明であった。今回、北海道で本症患者が確認され るとともに、ヤマトマダニから 2 株の本ウイルスが分離された。

5.ヤマトマダ二保有のリケッチア類 ………藤田博己（大原研究所）

わが国のヤマトマダニからは、古くリケッチア様小体の分離例（Saito、1962） がある。最近ではEhrlichia 属と日本紅斑熱病原体を含む複数種のリケッチアの 分離ないしは検出例が集積されつつある。

6.ヤマトマダ二媒介性ボレリア 増沢俊幸（静岡県立大学）

分子生物学的アプローチにより、ボレリア各種と媒介マダニ種との関連性につ いて考察した上で、ヤマトマダニの媒介するボレリアBorrelia japonica の病原性 について、in vivo あるいは in vitro 実験の結果を踏まえて解説したい。

世話人：高田伸弘干910-11 福井県松岡町 福井医科大学 Tel 0776-61-3111 / Fax 0776-25-0663 